Atmos. Chem. Phys., 18, 12477-12489, 2018

https://doi.org/10.5194/acp-18-12477-2018

(C) Author(s) 2018. This work is distributed under

the Creative Commons Attribution 4.0 License.

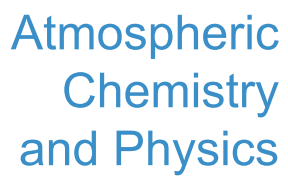

(c) (P)

\title{
Cloud droplet activation of black carbon particles coated with organic compounds of varying solubility
}

\author{
Maryam Dalirian $^{1}$, Arttu Ylisirniö ${ }^{2}$, Angela Buchholz ${ }^{2}$, Daniel Schlesinger ${ }^{1}$, Johan Ström ${ }^{1}$, Annele Virtanen $^{2}$, and \\ Ilona Riipinen ${ }^{1}$ \\ ${ }^{1}$ Department of Environmental Science and Analytical Chemistry (ACES) and the Bolin Centre for Climate research, \\ Stockholm University, Stockholm, Sweden \\ ${ }^{2}$ Department of Applied Physics, University of Eastern Finland, Kuopio, Finland
}

Correspondence: Maryam Dalirian (maryam.dalirian@aces.su.se) and Ilona Riipinen (ilona.riipinen@aces.su.se)

Received: 21 November 2017 - Discussion started: 4 December 2017

Revised: 17 June 2018 - Accepted: 22 June 2018 - Published: 28 August 2018

\begin{abstract}
Atmospheric black carbon (BC) particles are a concern due to their impact on air quality and climate. Their net climate effect is, however, still uncertain. This uncertainty is partly related to the contribution of coated $\mathrm{BC}$ particles to the global cloud condensation nuclei $(\mathrm{CCN})$ budgets. In this study, laboratory measurements were performed to investigate CCN activity of BC (REGAL 400R pigment black) particles, in pure state or coated through evaporating and subsequent condensation of glutaric acid, levoglucosan (both water-soluble organics) or oleic acid (an organic compound with low solubility). A combination of soot particle aerosol mass spectrometer (SP-AMS) measurements and size distribution measurements with a scanning mobility particle sizer (SMPS) showed that the studied BC particles were nearly spherical agglomerates with a fractal dimension of 2.79 and that they were coated evenly by the organic species. The $\mathrm{CCN}$ activity of $\mathrm{BC}$ particles increased after coating with all the studied compounds and was governed by the fraction of organic material. The $\mathrm{CCN}$ activation of the $\mathrm{BC}$ particles coated by glutaric acid and levoglucosan were in good agreement with the theoretical calculations using the shell-andcore model, which is based on a combination of the $\mathrm{CCN}$ activities of the pure compounds. The oleic acid coating enhanced the CCN activity of the BC particles, even though the pure oleic acid particles were $\mathrm{CCN}$ inactive. The surprising effect of oleic acid might be related to the arrangement of the oleic acid molecules on the surface of the BC cores or other surface phenomena facilitating water condensation onto the coated particles. Our results show that present theories have potential for accurately predicting the $\mathrm{CCN}$ activity
\end{abstract}

of atmospheric BC coated with organic species, given that the identities and amounts of the coating species are known. Furthermore, our results suggest that even relatively thin soluble coatings (around $2 \mathrm{~nm}$ for the compounds studied here) are enough to make the insoluble $\mathrm{BC}$ particles $\mathrm{CCN}$ active at typical atmospheric supersaturations and thus be efficiently taken up by cloud droplets. This highlights the need for an accurate description of the composition of atmospheric particles containing $\mathrm{BC}$ to unravel their net impact on climate.

\section{Introduction}

The effects of aerosols on climate and public health are central topics in atmospheric and environmental research. Atmospheric aerosols influence the energy balance of the Earth and the climate directly by scattering and absorbing solar and thermal radiation (McCormick and Ludwig, 1976; Haywood and Boucher, 2000; Ramanathan et al., 2001; IPCC, 2013) and indirectly by acting as cloud condensation nuclei (CCN) and ice nuclei (IN) and changing cloud microphysical properties (Twomey, 1974; Lohmann and Feichter, 2005; IPCC, 2013). High-concentration airborne particulate matter can also harm human health and causes millions of premature deaths every year (Mackay and Mensah, 2004; Pope and Dockery, 2006; Pope et al., 2009; Tranfield and Walker, 2012; Slezakova et al., 2013). Particles containing black carbon (BC) are of special importance because of their contribution to global warming. On one hand, they are estimated to be among the most important anthropogenic positive climate 
forcers after carbon dioxide and methane (Bond et al., 2013; IPCC, 2013) through their light-absorbing properties. At the same time, their contribution to CCN budgets is not well understood and drastically influenced by the mixing state of the atmospheric aerosol (Bond et al., 2013). BC-containing particles are emitted into the atmosphere from natural and anthropogenic sources through incomplete combustion of fossil fuels, biomass and biofuels (Bond et al., 2004). Freshly emitted BC particles are typically fractal aggregates and usually contain co-emitted organics such as adsorbed polyaromatic hydrocarbons (PAHs) produced during combustion (Marr et al., 2006). After emission, they undergo different aging processes and adsorb other organic and inorganic material produced by gas-to-particle conversion processes (Zhang et al., 2008; Canagaratna et al., 2015).

The structure and properties of $\mathrm{BC}$ particles in the atmosphere can vary considerably. Laboratory measurements have indicated that by increasing the amount of the coating on the $\mathrm{BC}$ particles, the dynamic shape factor of these particles decreases, and fractal BC aggregates become restructured and more compact (Saathoff et al., 2003; Slowik et al., 2007; Zhang et al., 2008; Pagels et al., 2009; Tritscher et al., 2011; Ghazi and Olfert, 2012). Investigating ambient $\mathrm{BC}$ particles has shown that BC particles coated by secondary aerosol constituents during atmospheric aging transform from fractal to spherical and further fully compact shapes (Peng et al., 2016; Zhang et al., 2016). Furthermore, ambient $\mathrm{BC}$ measurements have demonstrated that aging of $\mathrm{BC}$ particles and coating by other material via condensation and coagulation can enhance the light absorption capability of BC particles (Khalizov et al., 2009; Moffet and Prather, 2009; Chan et al., 2011; Liu et al., 2015; Zhang et al., 2018; Xu et al., 2018). This enhancement of light adsorption properties of $\mathrm{BC}$-containing particles is still a large uncertainty in modeling direct radiative forcing of BC. In addition, there are uncertainties in modeling the indirect radiative forcing of the $\mathrm{BC}$-containing particles, due to, e.g., lack of knowledge about cloud interactions of BC-containing particles and the role of the co-emitted species. To overcome these uncertainties, several studies have recently investigated the structure, hygroscopic growth and CCN activation of BC mixed with other, usually more water-soluble, species. Some of these studies have indicated that by increasing the amount of the coating on the BC particles, the dynamic shape factor of these particles decreases, and fractal $\mathrm{BC}$ aggregates become restructured and more compact (Saathoff et al., 2003; Slowik et al., 2007; Zhang et al., 2008; Pagels et al., 2009; Tritscher et al., 2011; Ghazi and Olfert, 2012). The hygroscopic growth factors (HGFs) and CCN activation of BC particles coated with various species have also been investigated in other studies (Saathoff et al., 2003; Dusek et al., 2006; Hings et al., 2008; Zhang et al., 2008; Henning et al., 2010, 2012; Stratmann et al., 2010; Tritscher et al., 2011; Maskey et al., 2017). These studies showed that the adsorption of water onto the slightly soluble part of the coated particles in- creases water uptake and HGFs and facilitates the process of adsorption activation (CCN activity). Despite the mentioned studies, $\mathrm{CCN}$ activation measurements of $\mathrm{BC}$ particles containing a soluble fraction are still relatively scarce.

The CCN activation of pure and coated insoluble particles, such as BC particles coated with soluble species, is usually described theoretically by multilayer adsorption models accounting for the curvature of the particles. One of these theories is adsorption activation theory (Sorjamaa and Laaksonen, 2007; Kumar et al., 2009) which is a combination of FHH (Frenkel-Halsey-Hill) adsorption isotherms and classical Köhler theory to describe the equilibrium growth of insoluble particles. Later, Kumar et al. (2011) introduced a new framework of CCN activation of dust containing a soluble salt fraction, based on a combination of the classical Köhler and FHH adsorption theories. However, systematic experimental testing of the applicability of combined Köhler and FHH theories with agglomerated insoluble particles coated with organic species of varying solubility is lacking. Meanwhile, the development and deployment of the soot particle aerosol mass spectrometer (SP-AMS) in recent years has resulted in enhanced knowledge about the composition and structure of fresh and aged BC-containing particles (Onasch et al., 2012; Willis et al., 2014; Canagaratna et al., 2015) but uncertainties still remain about the exact characteristics of ambient BC, related to, e.g., morphology of the freshly emitted and aged $\mathrm{BC}$ particles and their importance for aerosolcloud interaction.

The main aim of this study was to gain further insight on the structure and $\mathrm{CCN}$ activity of $\mathrm{BC}$ particles with various degrees of coating with atmospheric organic molecules and to test the applicability of combined Köhler and FHH theory with agglomerated insoluble particles coated with organic species of varying solubility. Laboratory measurements were performed to study the CCN activity of the pure and coated $\mathrm{BC}$ particles, and the experimental CCN activity results were compared to theoretical calculations using the framework introduced by Kumar et al. (2011). Furthermore, SP-AMS measurements of the pure and coated BC particles combined with the size distribution measurements with a SMPS provided more information about the size and morphology of the produced particles.

\section{Experimental methods}

\subsection{Particle generation and coating}

In Fig. 1, we present the schematic of the experimental setup for the generation, coating and characterization of sizeselected BC particles. For these experiments, we used atomized REGAL 400R pigment black (Cabot Corp.) as a core and coated it with organics of different solubilities in water. REGAL black is a surrogate for collapsed soot (Sedlacek et al., 2015) and is the recommended calibration standard 
for the SP-AMS (Onasch et al., 2012). This compound has been used in different studies (Onasch et al., 2012; Corbin et al., 2014; Healy et al., 2015; Sedlacek et al., 2015) as a model of refractory carbonaceous compounds to estimate the chemical and physical properties of the black carbon particles. Canagaratna et al. (2015) have shown that REGAL black and flame soot appear very similar, at least from the perspective of the mass spectrometry. However, it should of course be borne in mind that in the ambient setting, BC particles can vary significantly in terms of their physical and chemical properties, and are usually mixed with other pollutants present in the atmosphere. The components selected to coat the BC particles were glutaric acid and levoglucosan, which are soluble in water, and oleic acid, which is a sparingly soluble fatty acid (Table 1). Glutaric acid is one of the products of photochemical oxidation of unsaturated hydrocarbons and fatty acids. It can also be emitted directly into the atmosphere from coal and biomass burning (Kawamura and Yasui, 2005; Li et al., 2013). Levoglucosan is a major organic component emitted into the atmosphere from decomposition of wood during forest fires. Levoglucosan has been detected in aerosol particles at distances far from the combustion sources and is often used as an indicator for biomass burning in air quality studies (Simoneit et al., 1999). Oleic acid is a monounsaturated carboxylic acid, released to the atmosphere, e.g., during meat cooking, and has been used as a chemical tracer for these kinds of particulate matter emissions (Rogge et al., 1991; He et al., 2004). It should be mentioned that the studied organic substances were chosen based on their properties, not solely based on their atmospheric relevance. The solubility and other properties of atmospheric organic material vary considerably (e.g., Goldstein and Galbally, 2007; Jimenez et al., 2009) and this variation directed the selection of these materials.

All of the organic components were acquired from SigmaAldrich and had purities higher than $99 \%$. BC particles were produced using the atomization-drying method described in Keskinen et al. (2011). Particles were generated by an aerosol generator (model 3076, TSI Inc., USA) from a suspension of approximately $3 \mathrm{~g} \mathrm{~L}^{-1}$ REGAL black (RB) in a mixture of de-ionized water (model Maxima LS., USF Elga Ltd. with a production resistivity $>10 \mathrm{M} \Omega \mathrm{cm}$ and total organic carbon (TOC) concentration $<5 \mathrm{ppb}$ ) and ethanol (volume ratio $2: 1)$. The generated polydisperse particles were passed through a custom-made silica gel diffusion drier (Fig. 1) to reach a relative humidity $(\mathrm{RH})$ below $5 \%$. Thereafter, the particles were neutralized using a radioactive ${ }^{14} \mathrm{C}$ charge neutralizer and size-selected with a custom-made Viennatype differential mobility analyzer (DMA) (Winklmayr et al., 1991) with sample-to-sheath flow rate of 1.5 to $10 \mathrm{slpm}$. The particles were coated with the chosen organic compound using a tube furnace (Vecstar, model VCTF3). In the coating furnace, the size-selected BC particles were passed through a heated glass tube containing a vessel with the desired coating material. After first evaporating the organic vapor into the

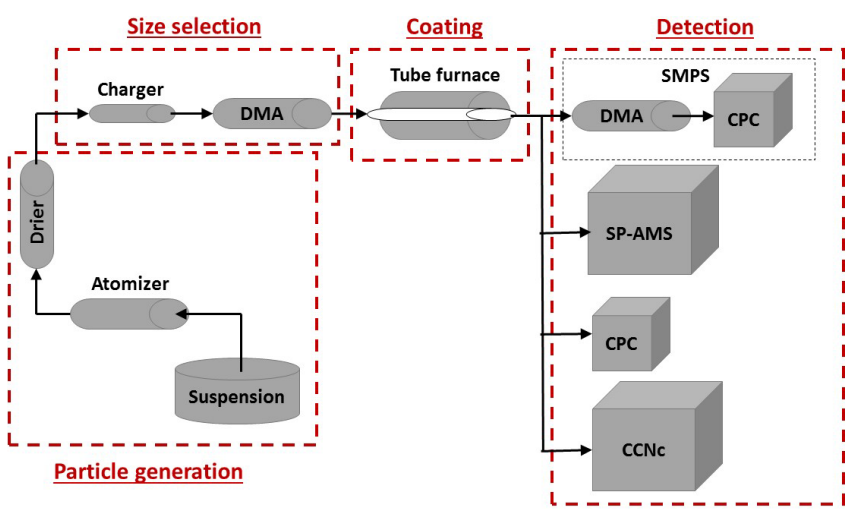

Figure 1. Schematic of the experimental setup, including particle generation using an atomizer and a drier, size selection with a differential mobility analyzer (DMA), coating and three types of measurements: $\mathrm{CCN}$ activity measurements using a condensation particle counter (CPC) and a cloud condensation nuclei counter (CCNc), size distribution measurements by a scanning mobility particle sizer (SMPS) and particle composition analysis by a soot particle aerosol mass spectrometer (SP-AMS).

particle stream and then cooling the mixture to room temperature, the organic species condensed on the BC particles. No formation of new particles from the coating material was observed. The saturation vapor pressure of each coating compound determined the furnace temperatures needed to produce the coating. The strong temperature dependence of the saturation vapor pressure resulted in varying concentrations of organic vapor at different furnace temperatures and thus ultimately different coating thicknesses for different coating substances. The coating thicknesses of organic species on the $\mathrm{BC}$ cores at different furnace temperatures are presented in Table 2 .

\subsection{Particle size distribution measurements}

The mobility diameter of the produced pure and coated BC particles was measured using a SMPS with sample-to-sheath flow ratio of 1.5 to $10 \mathrm{slpm}$. The SMPS was composed of a DMA (model 3071; TSI, Inc.) to classify particle bins according to their electrical mobilities, and a condensation particle counter (CPC model 3775; TSI, Inc.) to count the selected particles after the DMA.

\subsection{Characterization of the particles by SP-AMS}

A SP-AMS was used to investigate the chemical composition and aerodynamic size of particles containing $\mathrm{BC}$ and the organic coatings. The SP-AMS is a combination of the high-resolution time-of-flight aerosol mass spectrometer (AMS, Aerodyne Research Inc.) and the single particle soot photometer (SP2, Droplet Measurement Technologies Inc.). The SP-AMS has been described in detail in the literature (Onasch et al., 2012; Corbin et al., 2014; Willis et al., 2014; 
Table 1. Thermodynamic properties of components used in this study.

\begin{tabular}{|c|c|c|c|c|c|}
\hline & $\begin{array}{r}\text { Molar mass } \\
\left(\mathrm{g} \mathrm{mol}^{-1}\right)\end{array}$ & $\begin{array}{r}\text { Density } \\
\left(\mathrm{g} \mathrm{cm}^{-3}\right)\end{array}$ & $\begin{array}{r}\text { Solubility in } \\
\text { water }\left(\mathrm{mol} \mathrm{kg}^{-1}\right)\end{array}$ & $\begin{array}{r}\text { Vapor pressure } \\
\text { at } 25^{\circ} \mathrm{C}(\mathrm{Pa})\end{array}$ & $\kappa$ \\
\hline REGAL black & & $1.7-1.9^{\mathrm{c}}$ & Insoluble ${ }^{c}$ & & \\
\hline Glutaric acid & $132.16^{\mathrm{a}}$ & $1.429^{\mathrm{a}}$ & $10.8^{\mathrm{e}}\left(\right.$ at $\left.25^{\circ} \mathrm{C}\right)$ & $8.5 \times 10^{-4 h}$ & $0.113-0.376^{\mathrm{k}}$ \\
\hline Levoglucosan & $162.14^{\mathrm{b}}$ & $1.7 \pm 0.1^{\mathrm{d}}$ & $8.23^{\mathrm{f}}\left(\right.$ at $\left.20^{\circ} \mathrm{C}\right)$ & $4.65 \times 10^{-5 i}$ & $0.193-0.223^{\mathrm{k}}$ \\
\hline Oleic acid & $282.46^{\mathrm{a}}$ & $0.894^{\mathrm{a}}$ & Very low, $3.76 \times 10^{-9 g}$ & $1.9 \times 10^{-6 \mathrm{j}}$ & \\
\hline
\end{tabular}

${ }^{a}$ Haynes et al. (2017). ${ }^{b}$ Sigma-Aldrich, Chemie GmbH. ${ }^{c}$ REGAL $400 R$ pigment black safety data sheet, Cabot Corp. ${ }^{d}$ Predicted, ACD/Labs Percepta Platform - PhysChem Module. ${ }^{\mathrm{e}}$ Soonsin et al. (2010). ${ }^{\mathrm{f}}$ Zamora et al. (2011). ${ }^{\mathrm{g}}$ Demond and Lindner (1993). ${ }^{\mathrm{h}}$ Salo et al. (2010). ${ }^{i}$ Booth et al. (2011). j Cappa et al. (2008). ${ }^{k}$ Petters and Kreidenweis (2007).

Table 2. Coating thicknesses of organic species on the BC cores at different temperatures of the coating furnace.

\begin{tabular}{|c|c|c|c|}
\hline \multirow[b]{2}{*}{ Furnace temperature $\left({ }^{\circ} \mathrm{C}\right)$} & \multicolumn{3}{|c|}{ Coating thickness (nm) } \\
\hline & Core diameter $150 \mathrm{~nm}$ & Core diameter $200 \mathrm{~nm}$ & Core diameter $250 \mathrm{~nm}$ \\
\hline & \multicolumn{3}{|c|}{ Glutaric acid coating } \\
\hline 82 & 6 & 3 & 2 \\
\hline 88 & 13 & 9 & 4 \\
\hline \multirow[t]{2}{*}{91} & 17 & 3 & 8 \\
\hline & \multicolumn{3}{|c|}{ Levoglucosan coating } \\
\hline 94 & 5 & 4 & 3 \\
\hline 99 & 9 & 6 & 5 \\
\hline 104 & 19 & 13 & 9 \\
\hline 107 & 30 & 22 & 16 \\
\hline \multirow[t]{2}{*}{110} & & 27 & 20 \\
\hline & \multicolumn{3}{|c|}{ Oleic acid coating } \\
\hline 97 & 7 & 4 & 2 \\
\hline 100 & 11 & 7 & 5 \\
\hline 104 & 20 & 17 & 18 \\
\hline
\end{tabular}

Ahern et al., 2016). Briefly, in an AMS, the gas phase is removed through differential pumping and the particles are focused into a narrow beam. The particles are separated by vacuum aerodynamic diameter in a particle time-of-flight region before they are vaporized, ionized and analyzed by a time-of-flight mass spectrometer (DeCarlo et al., 2006). The key difference compared to a standard AMS is that in addition to a tungsten vaporizer, which operates at $600^{\circ} \mathrm{C}$, the instrument contains an intracavity infrared (IR) laser module which heats refractory particles up to around $4000{ }^{\circ} \mathrm{C}$ (SP mode). The tungsten vaporizer vaporizes only the nonrefractory organic particulate matter and the intracavity IR laser the refractory $\mathrm{BC}$ particles which do not evaporate even at $600{ }^{\circ} \mathrm{C}$ (Onasch et al., 2012; Corbin et al., 2014; Willis et al., 2014; Canagaratna et al., 2015). At very high temperatures in the SP mode, also non-refractory material on the BC particles will be evaporated, but the resulting mass spectra are not comparable with the standard ones generated with the tungsten vaporizer. Thus, the two evaporation methods were alternated, and any presented information about the BC core stems from SP mode while the information on the organic coating material was gathered from the tungsten vaporizer mode.

\subsection{CCN activity}

The CCN activity of the pure and coated BC particles was measured using a continuous flow streamwise thermal gradient CCN counter (CCNc; Droplet Measurement Technologies Inc.) (Roberts and Nenes, 2005) (Fig. 1). In the CCNc, the size-selected aerosol was exposed to water supersaturation between $0.1 \%$ and $1.5 \%$. Particles that activate to cloud droplets at the set supersaturation will grow large enough to be detected by the optical particle counter at the outlet of the $\mathrm{CCNc}$. The ratio of the number concentration of activated particles and the total particle concentration measured with a CPC (model 3772, TSI Inc.) yields the activated fraction. The supersaturation at which the activated fraction is $50 \%$ of the full activation is defined as the critical supersaturation $\left(s_{\mathrm{c}}\right)$ for the given dry particle size. The set supersaturation 
was calibrated by measuring ammonium sulfate particles and comparing to theoretically calculated values.

\section{Data analysis and theoretical methods}

\subsection{Morphology of the $\mathrm{BC}$ particles}

The measurements with the SP-AMS and SMPS instruments provided information on the vacuum aerodynamic diameter $\left(d_{\mathrm{va}}\right)$ and the mobility diameter $\left(d_{\mathrm{m}}\right)$ of the pure and coated BC particles. The relationship between these two diameters could yield information about the morphology and composition of the pure and coated $\mathrm{BC}$ particles.

The particle effective density ( $\left.\rho_{\text {eff }}\right)$ can be used as a measure of the non-sphericity of the particles. It is the density of the sphere with a diameter $d_{\mathrm{m}}$ and the same mass of the particle in question (DeCarlo et al., 2004). The effective density of the BC particles was estimated using the measured diameters $d_{\mathrm{va}}$ and $d_{\mathrm{m}}$ as (Jimenez et al., 2003)

$\rho_{\mathrm{eff}}=\rho_{0} \frac{d_{\mathrm{va}}}{d_{\mathrm{m}}}$,

where $\rho_{0}$ is unit density $\left(1.00 \mathrm{~g} \mathrm{~cm}^{-3}\right)$. For spheres, the effective density is the same as particle density $\left(\rho_{\text {eff }}=\rho_{\mathrm{p}}\right)$, while for agglomerates, $\rho_{\mathrm{eff}}<\rho_{\mathrm{p}}$ (DeCarlo et al., 2004).

The fractal dimension $\left(D_{\mathrm{f}}\right)$ is another parameter used to describe the geometry of agglomerated particles. For the BC particles, it was estimated by the scaling law equation for the effective density vs. the mobility diameter (Rogak and Flagan, 1990; Ström et al., 1992; Virtanen et al., 2004):

$\rho_{\text {eff }} \propto d_{\mathrm{m}}^{\left(D_{\mathrm{f}}-3\right)}$.

For spherical particles, $D_{\mathrm{f}}=3$, for compact agglomerates, $D_{\mathrm{f}} \approx 3$, and for straight chain-like structures, $D_{\mathrm{f}}=1$ (DeCarlo et al., 2004).

\subsection{CCN activation of the pure and coated BC particles}

In classical Köhler theory (Köhler, 1936; Seinfeld and Pandis, 2006), the saturation ratio of water vapor over a solution droplet of diameter $d_{\mathrm{p}}$ depends on the water activity $\left(a_{\mathrm{w}}\right)$ (Raoult effect) and droplet curvature (Kelvin effect):

$S=a_{\mathrm{w}} \exp \frac{4 \sigma_{\mathrm{w}} M_{\mathrm{w}}}{R T \rho_{\mathrm{w}} d_{\mathrm{p}}}$,

where $a_{\mathrm{w}}, \sigma_{\mathrm{w}}, M_{\mathrm{w}}$ and $\rho_{\mathrm{w}}$ are the activity, surface tension, molar mass and density of the water, respectively. $R$ is the universal gas constant, $T$ is the temperature, and $d_{\mathrm{p}}$ is the droplet diameter.

Köhler theory is applicable for water-soluble components like soluble organics and inorganic salts. It is not valid for insoluble or nearly insoluble compounds. Sorjamaa and Laaksonen (2007) assumed that multilayer adsorption of water molecules on the surface of the water-insoluble but wettable particles could describe cloud activation of these kinds of particles. Then, the Raoult term in the Köhler theory is controlled by the adsorption of water vapor on the surface of water-insoluble particles like BC (Sorjamaa and Laaksonen, 2007; Kumar et al., 2011). Assuming equilibrium between the adsorbed water on the surface of the particles and the surrounding water vapor, the activity of water is given as (Kumar et al., 2011)

$a_{\mathrm{w}}=x_{\mathrm{w}} \exp \left(-A \theta^{B}\right)$,

where $x_{\mathrm{w}}$ is the mole fraction of the water molecules, and $A$ and $B$ are the FHH adsorption theory parameters. FHH adsorption theory is one of the multilayer adsorption models applicable at pressures close to saturation. The parameter $A$ defines the interactions between the molecules of adsorbed components as well as between the surface and adsorbate in the first monolayer. The parameter $B$ characterizes the interactions between the surface and the adsorbed molecules in adjacent layers. The parameters $A$ and $B$ are determined experimentally for each component. Parameter $A$ has been experimentally found to be in the range of $0.1-3.0$, while $B$ varies between 0.5 and 3.0 (Sorjamaa and Laaksonen, 2007). The amount of the adsorbed water is described by the surface coverage $(\theta)$, which is the adsorbed number of molecules divided by the number of molecules in a monolayer (Sorjamaa and Laaksonen, 2007):

$\theta=\frac{d_{\mathrm{p}}-d_{\mathrm{dry}}}{2 d_{\mathrm{w}}}$,

where $d_{\text {dry }}$ is the dry particle diameter, and $d_{\mathrm{w}}$ is the diameter of one water molecule. In the shell-and-core model introduced by Kumar et al. (2011), water vapor is assumed to be only adsorbed on the dry insoluble core, and the surface coverage $\theta$ is thus given as

$\theta=\frac{d_{\mathrm{p}}-d_{\text {core }}}{2 d_{\mathrm{w}}}$,

where $d_{\text {core }}$ is the diameter of the water-insoluble core. For water droplets generated by totally insoluble particles, the mole fraction $x_{\mathrm{w}}$ in Eq. (4) becomes 1, but for droplets made of particles containing an insoluble core covered by a soluble coating, $x_{\mathrm{w}}=1-x_{\mathrm{s}}$ and $x_{\mathrm{s}} \approx n_{\mathrm{s}} / n_{\mathrm{w}}$, where $n_{\mathrm{s}}$ and $n_{\mathrm{w}}$ are the numbers of solute and water molecules, respectively (Kumar et al., 2011). $x_{\mathrm{s}}$ can then be expressed by

$x_{s}=\frac{\left(V_{\text {dry }}-V_{\text {core }}\right) \rho_{\mathrm{s}} v / M_{\mathrm{s}}}{\left(V_{\mathrm{p}}-V_{\text {core }}\right) \rho_{\mathrm{w}} / M_{\mathrm{w}}}=\frac{\left(d_{\text {dry }}^{3}-d_{\text {core }}^{3}\right) \rho_{\mathrm{s}} v M_{\mathrm{w}}}{\left(d_{\mathrm{p}}^{3}-d_{\text {core }}^{3}\right) \rho_{\mathrm{w}} M_{\mathrm{s}}}$,

where $\rho_{\mathrm{S}}$ and $M_{\mathrm{S}}$ are the density and molar mass of the soluble part; $V_{\text {dry }}, V_{\text {core }}$ and $V_{\mathrm{p}}$ are the volume of the dry particle, volume of the insoluble core and volume of the droplet, respectively; and $v$ is the van 't Hoff factor. By assuming that 
the droplets are dilute solutions at the activation point, $\frac{\rho_{\mathrm{s}} v M_{\mathrm{W}}}{\rho_{\mathrm{W}} M_{\mathrm{S}}}$ becomes equal to the hygroscopicity parameter $(\kappa)$ (Petters and Kreidenweis, 2007; Chang et al., 2010) and substituting Eqs. (4), (6) and (7) in Eq. (3), the saturation ratio of the coated particles will be

$$
\begin{aligned}
S= & \left(1-\kappa \frac{\left(d_{\text {dry }} / d_{\text {core }}\right)^{3}-1}{\left(d_{\mathrm{p}} / d_{\text {core }}\right)^{3}-1}\right) \\
& \exp \left(\frac{4 \sigma_{\mathrm{w}} M_{\mathrm{w}}}{R T \rho_{\mathrm{w}} d_{\mathrm{p}}}-A\left(\frac{d_{\mathrm{p}}-d_{\text {core }}}{2 d_{\mathrm{w}}}\right)^{-B}\right) .
\end{aligned}
$$

The supersaturation $(s)$, which is equal to $(S-1)$, will then become (Kumar et al., 2011)

$s=\frac{4 \sigma_{\mathrm{w}} M_{\mathrm{w}}}{R T \rho_{\mathrm{w}} d_{\mathrm{p}}}-\kappa \frac{\left(d_{\text {dry }} / d_{\text {core }}\right)^{3}-1}{\left(d_{\mathrm{p}} / d_{\text {core }}\right)^{3}-1}-A\left(\frac{d_{\mathrm{p}}-d_{\text {core }}}{2 d_{\mathrm{w}}}\right)^{-B}$.

For pure BC particles with $d_{\text {dry }}=d_{\text {core, Eq. (8) can be re- }}$ duced to $\mathrm{FHH}$ adsorption activation theory (Sorjamaa and Laaksonen, 2007):

$s=\frac{4 \sigma_{\mathrm{w}} M_{\mathrm{w}}}{R T \rho_{\mathrm{w}} d_{\mathrm{p}}}-A\left(\frac{d_{\mathrm{p}}-d_{\mathrm{dry}}}{2 d_{\mathrm{w}}}\right)^{-B}$.

\section{Results and discussion}

\subsection{Particle shape and chemical composition}

Due to the agglomerated shape of the BC particles, the combination of vacuum aerodynamic $\left(d_{\mathrm{va}}\right)$ size measurements by SP-AMS and electrical mobility equivalent size $\left(d_{\mathrm{m}}\right)$ measurements using SMPS gave us insight on the shape of these particles. We did the measurements for pure BC particles with the mobility sizes from 150 to $300 \mathrm{~nm}$ and for BC cores with mobility diameters 150,200 and $250 \mathrm{~nm}$ coated by levoglucosan, glutaric acid or oleic acid.

The combination of the SP-AMS and SMPS provided $d_{\mathrm{va}}$ and $d_{\mathrm{m}}$, which yielded the effective density of the generated particles (Eq. 1). The resulting effective densities for pure BC particles with the mobility diameters from 150 to $300 \mathrm{~nm}$ are presented in Fig. 2. The measured effective densities are in good agreement with the effective densities measured in other studies for REGAL black and other BC particle types (Gysel et al., 2011, 2012; Onasch et al., 2012). The fractal dimension of the BC particles was estimated using the slopes of the curves in Fig. 2 and Eq. (2), resulting in a $D_{\mathrm{f}}$ value of 2.79, which is closer to spherical or compact aggregates $\left(D_{\mathrm{f}}=3\right)$ rather than chain-like structures $\left(D_{\mathrm{f}}=1\right)$. The fitted $D_{\mathrm{f}}$ value is also close to the value $\left(D_{\mathrm{f}} \approx 3\right)$ reported by Onasch et al. (2012) for the same BC type (REGAL 400R black) as we used in this study. These values suggest a compact shape of the studied BC particles. Therefore, we can assume that the organic coating only covers the BC cores like a shell. Hence, when calculating the critical supersaturations

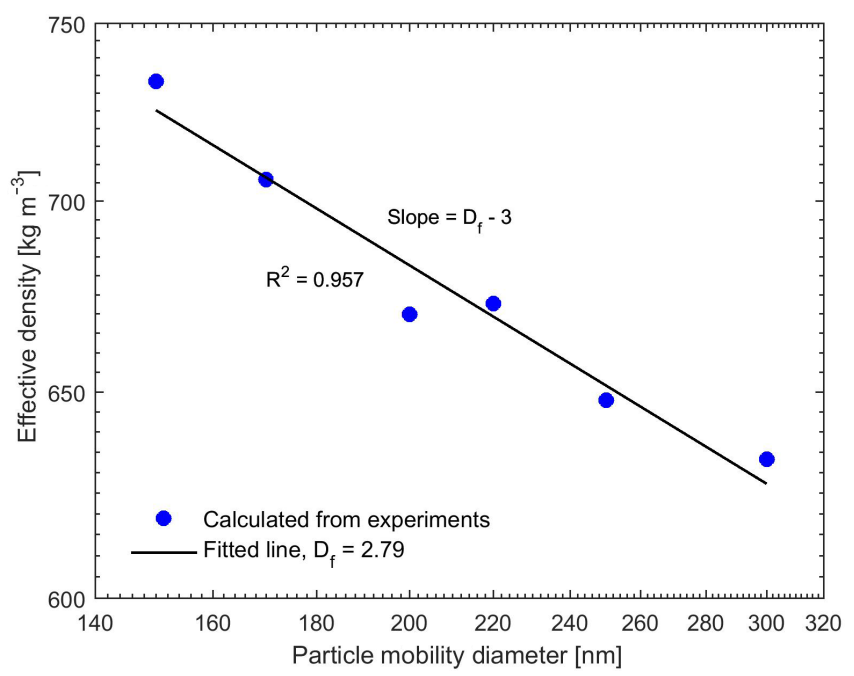

Figure 2. Effective density of the pure BC particles for different mobility diameters. The fitted fractal dimension is 2.79 .

of the pure and coated BC particles using Eqs. (9) and (10), the $d_{\text {core }}$ and $d_{\text {dry }}$ were thus approximated to be the same as the mobility diameter of the BC particles before and after coating.

From SP-AMS, $d_{\mathrm{va}}$ was derived for the total organic and $\mathrm{BC}$ signal separately for the coated particles (Fig. 3). The average particle sizes were slightly higher for the organic signal but generally in good agreement. Thus, the particles displayed a relatively even coating thickness; i.e., no uncoated $\mathrm{BC}$ particles or pure organic particles were observed.

\subsection{Cloud activation behavior of the uncoated and coated particles}

Experimentally and theoretically determined critical supersaturations of uncoated BC particles as a function of particle mobility diameter are shown in Fig. 4. Two sets of experimental data were collected under similar conditions but during two different time intervals, and the reported data are the average of these two data sets. As is evident from Fig. 4, the critical supersaturation decreases with increasing particle diameter as expected. The parameters $A$ and $B$ of the FHH adsorption isotherm are difficult to constrain uniquely using only the CCN activation data without any additional information about the growth rate of the droplet at critical supersaturation (Dalirian et al., 2015). Nevertheless, we fitted these parameters to the two $\mathrm{CCN}$ data sets with the constraints $0.1<A<3.0$ and $0.5<B<3.0$ (Sorjamaa and Laaksonen, 2007). The fitted values of $A$ and $B$ for Eq. (10) were 0.5 and 1.2 , respectively, and they reproduce the observations well as demonstrated in Fig. 4.

Figures 5 and 6 show the measured and theoretical critical supersaturations as a function of the total particle mobility diameter for BC core with glutaric acid and levoglucosan 


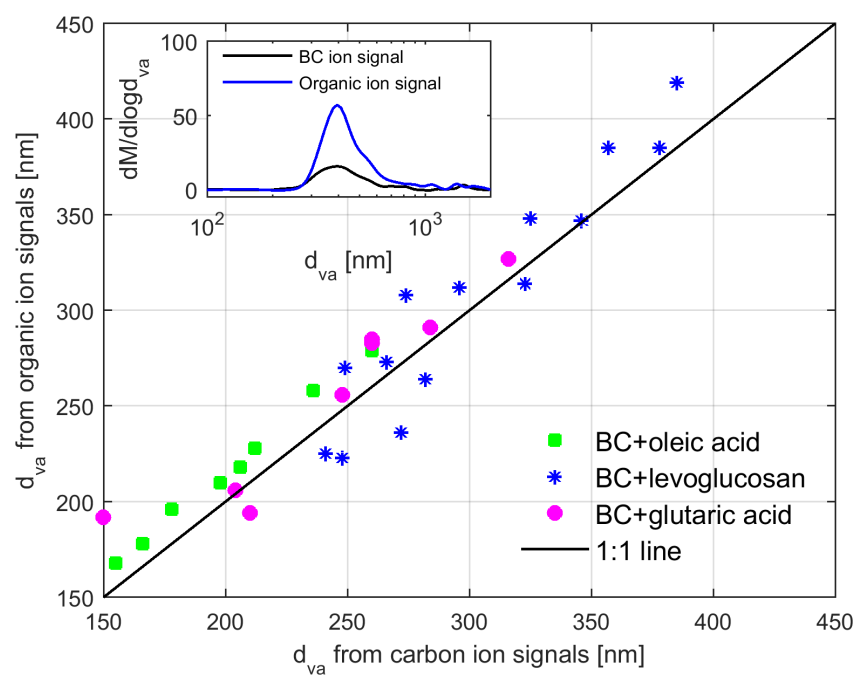

Figure 3. Vacuum aerodynamic diameters $\left(d_{\mathrm{va}}\right)$ from organic and carbon ion signals from SP-AMS for particles containing BC coated with various organic compounds. The inset represents mass size distribution vs. $d_{\mathrm{va}}$ extracted from $\mathrm{BC}$ and organic ion signals for monodispersed $200 \mathrm{~nm}$ BC particles coated by $27 \mathrm{~nm}$ levoglucosan. The coating thickness was estimated from the mobility size measurements by SMPS.

coating as well as pure $\mathrm{BC}$ and glutaric acid/levoglucosan particles. The values for the $s_{\mathrm{c}}$ of the pure glutaric acid and levoglucosan were calculated using the $\kappa$-Köhler theory (Petters and Kreidenweis, 2007). The shaded areas resulted from the varying values of the $\kappa$ parameter reported in the literature for pure glutaric acid and levoglucosan (see Table 1). The uncertainty range for theoretically calculated $s_{\mathrm{c}}$ is narrower for levoglucosan compared to glutaric acid, because the variation in reported $\kappa$ values used in the calculations is smaller for levoglucosan (see Table 1). As expected, the critical supersaturation is generally higher for pure $\mathrm{BC}$ particles than for the particles with organic coating, and the pure organic particles have the lowest critical supersaturation (see Figs. 5 and 6). Furthermore, the critical supersaturation decreases when the amount of organic coating in the particles increases. As shown in Figs. 5 and 6, the measured and calculated critical supersaturations for the coated particles are in good agreement, and by increasing the amount of organic coating the $s_{\mathrm{c}}$ values approach the values calculated for pure glutaric acid and levoglucosan. Nevertheless, there are small deviations between the measured and calculated critical supersaturations of the larger particles. The reason might be just a larger uncertainty in the $\kappa$ values than what is considered in the calculations. For example, different values have been reported for $\kappa$ of glutaric acid in different studies (Petters and Kreidenweis, 2007; Chan et al., 2008; Petters et al., 2016). The same trend was observed in the study done by Hings et al. (2008) for soot particles coated by adipic acid. For the coated particles with a specific insoluble core diam-

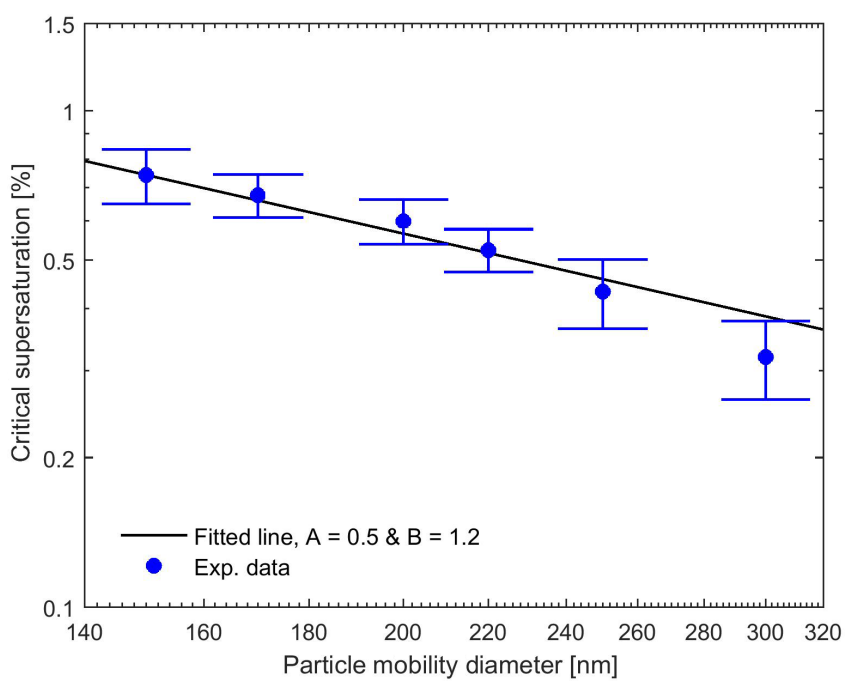

Figure 4. Experimental and theoretical critical supersaturations for pure BC particles for different particle mobility diameters. The theoretical curve were calculated with Eq. (10) with $A$ and $B$ as fitting parameters. The experimental data were the average of two sets of experiments. Error bars represent the minimum vs. maximum values of supersaturations from the two data sets.

eter, the amount of the organic coating dominates the $\mathrm{CCN}$ activity of these particles, and if the coating thickness is large enough compared to the initial core size, the particle will behave like pure organic.

The measured and calculated critical supersaturations as a function of the total particle mobility diameter for $\mathrm{BC}$ core plus oleic acid as well as the theoretical values for the pure $\mathrm{BC}$ are presented in Fig. 7. Since, according to the previous studies (Broekhuizen et al., 2004) and our CCNc measurements (at the measured supersaturations up to $1 \%$ ), oleic acid particulate matter is $\mathrm{CCN}$ inactive, no hygroscopicity data were available to calculate the theoretical values for the $s_{\mathrm{c}}$ of the pure oleic acid and the oleic-acid-coated BC particles. The CCN measurement results demonstrate that in spite of $\mathrm{CCN}$ inactivity of pure oleic acid, it enhances the CCN activity of the BC particles and $s_{\mathrm{c}}$ of these particles decreases with increasing degree of the oleic acid coating. One explanation for the enhancement in the $\mathrm{CCN}$ activation of the $\mathrm{BC}$ in the presence of almost insoluble oleic acid could simply be the lowering of the activation barrier to the activation by making the particle larger (Abbatt et al., 2005). However, in this case, the critical supersaturation would be expected to follow the black line in Fig. 7. Another explanation would be related to the arrangement of the oleic acid molecules on the surface of the $\mathrm{BC}$ cores as compared with pure oleic acid particles (Garland et al., 2008) or some other mechanism through which oleic acid modifies the BC surface. 


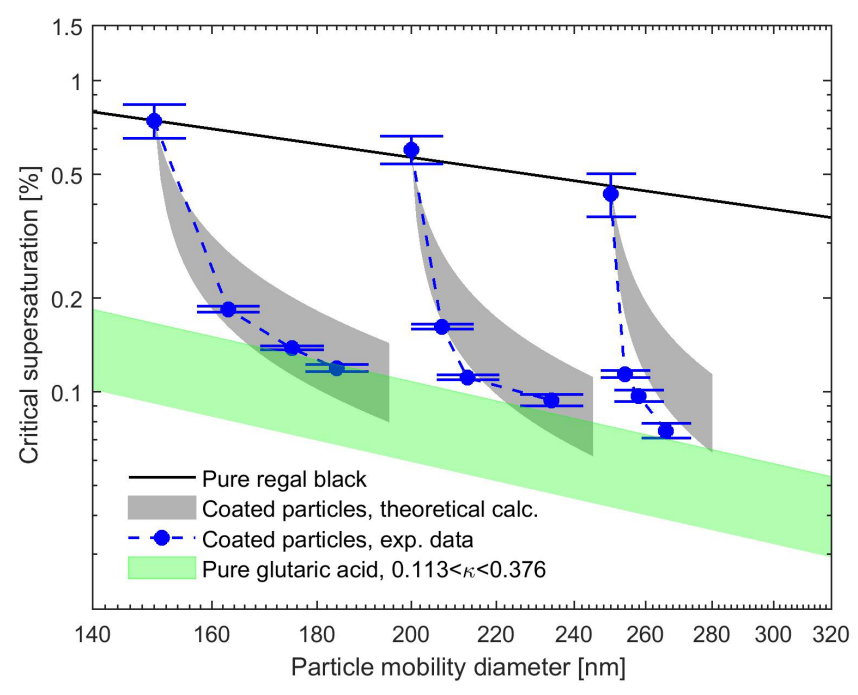

Figure 5. Experimental and theoretical critical supersaturations for BC particles coated by glutaric acid for different particle mobility diameters. The black line represents the calculated critical supersaturations of the pure BC particles using the FHH adsorption activation theory (Eq. 10). The gray shaded areas define the critical supersaturations calculated using Eq. (9) and variety of the $\kappa$ values reported in the literature for glutaric acid (see Table 1). The green shaded area represents the critical supersaturations from the $\kappa$-Köhler theory (Petters and Kreidenweis, 2007) for the pure glutaric acid particles with the range of $\kappa$ values from literature. Error bars represent the experimental uncertainty in the critical supersaturation $s_{\mathrm{C}}$ corresponding to each mobility diameter.

\section{Summary and conclusions}

In this study, the cloud droplet activation of uncoated and coated BC (REGAL black) particles was investigated. Three kinds of organic compounds were used as coating: glutaric acid, levoglucosan and oleic acid, which can be emitted into the atmosphere from different sources, e.g., biomass burning and meat cooking. Furthermore, the morphology and size of the produced particles were investigated based on SPAMS and SMPS measurements. In addition, the experimental CCN activity results were compared to theoretical calculations using the shell-and-core model introduced by Kumar et al. (2011).

Combining the measurements with SP-AMS and SMPS for uncoated $\mathrm{BC}$ particles suggested that our generated BC particles were agglomerates with fractal dimension of 2.79 , which is close to spherical particles $\left(D_{\mathrm{f}}=3\right)$. Therefore, we could assume that the organic coating only covered the $\mathrm{BC}$ cores like a shell. The coating procedure was performed for the size-selected $(150,200$ and $250 \mathrm{~nm}) \mathrm{BC}$ particles using a temperature-controlled tube furnace, which yielded different coating thicknesses of the desired organic compound. For the coated $\mathrm{BC}$ particles, the vacuum aerodynamic diameters derived from organic and $\mathrm{BC}$ ion signals in the particle timeof-flight region of SP-AMS also suggested a relatively even

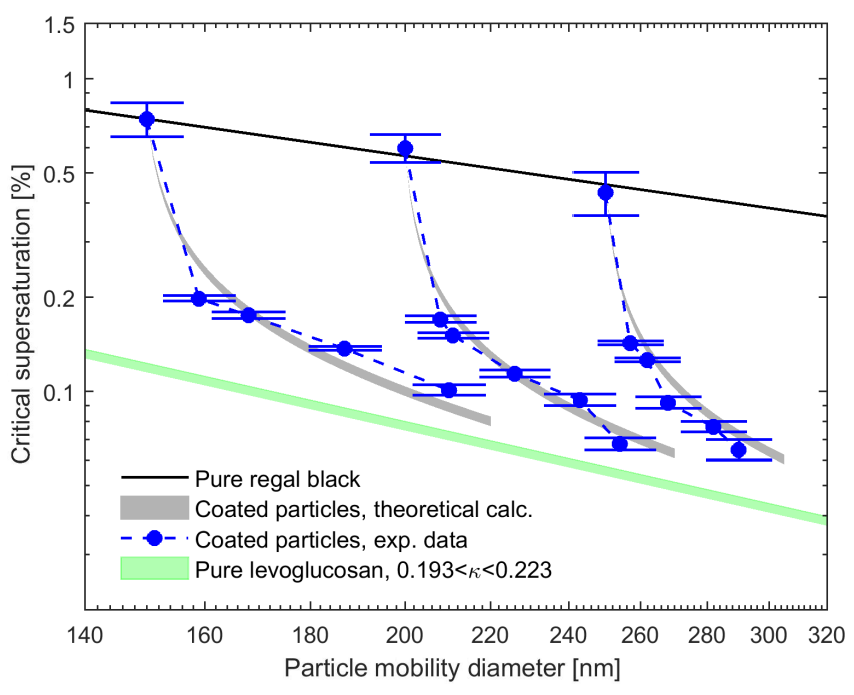

Figure 6. Experimental and theoretical critical supersaturations for BC particles coated by levoglucosan for different particle mobility diameters. The black line represents the calculated critical supersaturations of the pure BC particles using the FHH adsorption activation theory (Eq. 10). The gray shaded areas define the critical supersaturations calculated using Eq. (9) and variety of the $\kappa$ values reported in the literature for levoglucosan (see Table 1). The green shaded area represents the critical supersaturations from the $\kappa$-Köhler theory (Petters and Kreidenweis, 2007) for the pure levoglucosan particles with the range of $\kappa$ values from literature. Error bars represent the experimental uncertainty in the critical supersaturation $s_{\mathrm{c}}$ corresponding to each mobility diameter.

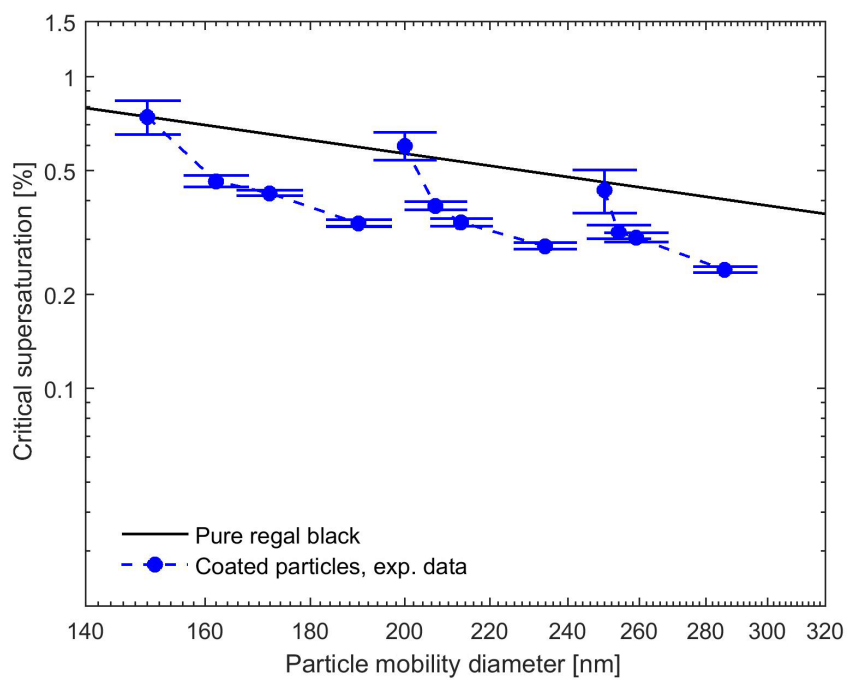

Figure 7. Experimental and theoretical critical supersaturations for coated BC by oleic acid for different particle mobility diameters. Black line represents the calculated critical supersaturations of the pure BC particles using FHH adsorption activation theory (Eq. 10). No CCN activation was observed for pure oleic acid particles. 
coating of the particles. No uncoated BC particles or pure organic particles were observed after the coating procedure.

$\mathrm{CCN}$ activity measurements were conducted at various supersaturations, and activation ratios and critical supersaturation curves were determined for the evaluated particles. Subsequently, the experimental data for the coated BC particles were compared to theoretical values using the shell-and-core model introduced by Kumar et al. (2011) describing CCN activation of coated insoluble components. Adsorption activation theory (e.g., Sorjamaa and Laaksonen, 2007) was used to fit the FHH adsorption parameters $(A=0.5$ and $B=1.2)$ for the uncoated $\mathrm{BC}$ particles. For the $\mathrm{BC}$ particles coated by glutaric acid and levoglucosan, the critical supersaturations from CCN activity measurements were in good agreement with values from theoretical calculations. As expected, the coating by organics increased the $\mathrm{CCN}$ activity of the $\mathrm{BC}$ particles. The $\mathrm{CCN}$ activity of the coated $\mathrm{BC}$ particles was governed by the fraction of organic material, and observed critical supersaturations asymptotically approached the values for pure glutaric acid and levoglucosan at larger coating thicknesses. Since the oleic acid particles were CCN inactive, no hygroscopicity data were available to calculate the $s_{\mathrm{c}}$ values for the pure oleic acid. Hence, no significant enhancement of CCN activity of BC by oleic acid coating was expected. However, our experimental results showed that despite the CCN inactivity of pure oleic acid, it enhanced the $\mathrm{CCN}$ activity of the $\mathrm{BC}$ particles more than a simple size effect would explain. One possible explanation for this behavior could be a rearrangement of the oleic acid molecules on the surface of the $\mathrm{BC}$ cores in such a way that the long hydrophobic alkyl chains cover the $\mathrm{BC}$ surface, exposing the strongly hydrophilic carboxyl groups, thus potentially providing sites to adsorb water molecules. Another possible explanation would be a decrease in surface tension due to the presence of oleic acid molecules at the interface, effectively decreasing the critical supersaturation.

Our results indicated that the amount of coating material (water-soluble or insoluble) BC particles adsorb during atmospheric aging is a parameter defining the $\mathrm{CCN}$ activation of these particles. For all the coating species considered in this study, relatively thin coatings (e.g., $2 \mathrm{~nm}$ coating that corresponds to about $5 \%$ of the total volume of a particle $250 \mathrm{~nm}$ in diameter) were enough to significantly enhance the $\mathrm{CCN}$ activity of the insoluble BC particles. We also conclude that the shell-and-core model by Kumar et al. (2011), which was originally introduced for fresh dust coated by a layer of soluble salt after aging, gives a reasonable estimate of the $\mathrm{CCN}$ activity of insoluble cores coated by soluble organics. Specific molecular interactions between $\mathrm{BC}$ and some coating molecules (like oleic acid in our case) can however yield surprising results in terms of the CCN activity of these particles. The oleic acid results simply highlight the need for laboratory measurements with simple model compounds. Another interesting topic for a future study would be a systematic study of coated particles with a given size but varying coat- ing thicknesses. Our results showed that by using the existing model frameworks, we cannot explain all of the experimental observations, but more theoretical work is needed. Our results further demonstrated that $\mathrm{BC}$ particles may transform into $\mathrm{CCN}$ if other material is available to condense on the particles. In ambient conditions, most $\mathrm{BC}$ resides as internal mixtures with other aerosol species. Hence, there is a need to include the impacts of co-emitted or later-condensed soluble species in estimates of the climate impacts by $\mathrm{BC}$ particles.

Data availability. The raw data are available upon request to the corresponding authors (ilona.riipinen@aces.su.se and maryam.dalirian@aces.su.se).

Author contributions. MD, IR and AV designed the study. MD, AY, $\mathrm{AB}$ and $\mathrm{AV}$ conducted the experiments. MD, AY, AB, DS, JS and $\mathrm{AV}$ analysed the data. MD, IR and AV wrote the manuscript with contributions from all co-authors.

Competing interests. The authors declare that they have no conflict of interest.

Acknowledgements. Financial support from the Nordic Centre of Excellence CRAICC (Cryosphere-atmosphere interactions in a changing Arctic climate), Vetenskaprådet (grant no. 2011-5120) and the Knut and Alice Wallenberg Foundation (Wallenberg Academy Fellowship AtmoRemove) is gratefully acknowledged.

Edited by: Maria Cristina Facchini

Reviewed by: two anonymous referees

\section{References}

Abbatt, J., Broekhuizen, K., and Pradeepkumar, P.: Cloud condensation nucleus activity of internally mixed ammonium sulfate/organic acid aerosol particles, Atmos. Environ., 39, 47674778, https://doi.org/10.1016/j.atmosenv.2005.04.029, 2005.

Ahern, A. T., Subramanian, R., Saliba, G., Lipsky, E. M., Donahue, N. M., and Sullivan, R. C.: Effect of secondary organic aerosol coating thickness on the real-time detection and characterization of biomass-burning soot by two particle mass spectrometers, Atmos. Meas. Tech., 9, 6117-6137, https://doi.org/10.5194/amt-96117-2016, 2016.

Bond, T. C., Streets, D. G., Yarber, K. F., Nelson, S. M., Woo, J. H., and Klimont, Z.: A technology-based global inventory of black and organic carbon emissions from combustion, J. Geophys. Res.-Atmos., 109, 1-43, https://doi.org/10.1029/2003JD003697, 2004.

Bond, T. C., Doherty, S. J., Fahey, D. W., Forster, P. M., Berntsen, T., Deangelo, B. J., Flanner, M. G., Ghan, S., Kärcher, B., Koch, D., Kinne, S., Kondo, Y., Quinn, P. K., Sarofim, M. C., Schultz, M. G., Schulz, M., Venkataraman, C., Zhang, H., Zhang, S., Bellouin, N., Guttikunda, S. K., Hopke, P. K., Jacobson, M. 
Z., Kaiser, J. W., Klimont, Z., Lohmann, U., Schwarz, J. P., Shindell, D., Storelvmo, T., Warren, S. G., and Zender, C. S.: Bounding the role of black carbon in the climate system: A scientific assessment, J. Geophys. Res.-Atmos., 118, 5380-5552, https://doi.org/10.1002/jgrd.50171, 2013.

Booth, A. M., Montague, W. J., Barley, M. H., Topping, D. O., McFiggans, G., Garforth, A., and Percival, C. J.: Solid state and sub-cooled liquid vapour pressures of cyclic aliphatic dicarboxylic acids, Atmos. Chem. Phys., 11, 655-665, https://doi.org/10.5194/acp-11-655-2011, 2011.

Broekhuizen, K. E., Thornberry, T., Kumar, P. P., and Abbatt, J. P. D.: Formation of cloud condensation nuclei by oxidative processing: Unsaturated fatty acids, J. Geophys. Res.-Atmos., 109, 1-8, https://doi.org/10.1029/2004JD005298, 2004.

Canagaratna, M. R., Massoli, P., Browne, E. C., Franklin, J. P., Wilson, K. R., Onasch, T. B., Kirchstetter, T. W., Fortner, E. C., Kolb, C. E., Jayne, J. T., Kroll, J. H., and Worsnop, D. R.: Chemical compositions of black carbon particle cores and coatings via soot particle aerosol mass spectrometry with photoionization and electron ionization, J. Phys. Chem. A, 119, 45894599, https://doi.org/10.1021/jp510711u, 2015.

Cappa, C. D., Lovejoy, E. R., and Ravishankara, A. R.: Evaporation Rates and Vapor Pressures of the Even-Numbered $\mathrm{C}_{8}$ $\mathrm{C}_{18}$ Monocarboxylic Acids, J. Phys. Chem. A, 112, 3959-3964, 2008.

Chan, M. N., Kreidenweis, S. M., and Chan, C. K.: Measurements of the hygroscopic and deliquescence properties of organic compounds of different solubilities in wate rand their relationship with cloud condensation nuclei activities, Environ. Sci. Technol., 42, 3602-3608, 2008.

Chan, T. W., Brook, J. R., Smallwood, G. J., and Lu, G.: Time-resolved measurements of black carbon light absorption enhancement in urban and near-urban locations of southern Ontario, Canada, Atmos. Chem. Phys., 11, 10407-10432, https://doi.org/10.5194/acp-11-10407-2011, 2011.

Chang, R. Y.-W., Slowik, J. G., Shantz, N. C., Vlasenko, A., Liggio, J., Sjostedt, S. J., Leaitch, W. R., and Abbatt, J. P. D.: The hygroscopicity parameter $(\kappa)$ of ambient organic aerosol at a field site subject to biogenic and anthropogenic influences: relationship to degree of aerosol oxidation, Atmos. Chem. Phys., 10, 5047-5064, https://doi.org/10.5194/acp-10-5047-2010, 2010.

Corbin, J. C., Sierau, B., Gysel, M., Laborde, M., Keller, A., Kim, J., Petzold, A., Onasch, T. B., Lohmann, U., and Mensah, A. A.: Mass spectrometry of refractory black carbon particles from six sources: carbon-cluster and oxygenated ions, Atmos. Chem. Phys., 14, 2591-2603, https://doi.org/10.5194/acp14-2591-2014, 2014.

Dalirian, M., Keskinen, H., Ahlm, L., Ylisirniö, A., Romakkaniemi, S., Laaksonen, A., Virtanen, A., and Riipinen, I.: CCN activation of fumed silica aerosols mixed with soluble pollutants, Atmos. Chem. Phys., 15, 3815-3829, https://doi.org/10.5194/acp15-3815-2015, 2015.

DeCarlo, P. F., Slowik, J. G., Worsnop, D. R., Davidovits, P., and Jimenez, J. L.: Particle morphology and density characterization by combined mobility and aerodynamic diameter measurements. Part 1: theory, Aerosol Sci. Tech., 38, 1185-1205, https://doi.org/10.1080/027868290903907, 2004.

DeCarlo, P. F., Kimmel, J. R., Trimborn, A., Northway, M. J., Jayne, J. T., Aiken, A. C., Gonin, M., Fuhrer,
K., Horvath, T., Docherty, K. S., Worsnop, D. R., and Jimenez, J. L.: Field-deployable, high-resolution, time-of-flight aerosol mass spectrometer, Anal. Chem., 78, 8281-8289, https://doi.org/10.1021/ac061249n, 2006.

Demond, A. H. and Lindner, A. S.: Estimation of interfacial tension between organic liquid mixtures and water., Environ. Sci. Technol., 27, 2318-2331, https://doi.org/10.1021/es901061k, 1993.

Dusek, U., Reischl, G. P., and Hitzenberger, R.: CCN activation of pure and coated carbon black particles, Environ. Sci. Technol., 40, 1223-1230, 2006.

Garland, E. R., Rosen, E. P., Clarke, L. I., and Baer, T.: Structure of submonolayer oleic acid coverages on inorganic aerosol particles: evidence of island formation, Phys. Chem. Chem. Phys., 10, 3156, https://doi.org/10.1039/b718013f, 2008.

Ghazi, R. and Olfert, J. S.: Coating Mass Dependence of Soot Aggregate Restructuring Due to Coatings of Oleic Acid and Dioctyl Sebacate, Aerosol Sci. Tech., 47, 192-200, https://doi.org/10.1080/02786826.2012.741273, 2012.

Goldstein, A. H. and Galbally, I. E.: Known and unexplored organic constituents in the earth's atmosphere, Environ. Sci. Technol., 41, 1514-1521, https://doi.org/10.1021/es072476p, 2007.

Gysel, M., Laborde, M., Olfert, J. S., Subramanian, R., and Gröhn, A. J.: Effective density of Aquadag and fullerene soot black carbon reference materials used for SP2 calibration, Atmos. Meas. Tech., 4, 2851-2858, https://doi.org/10.5194/amt-4-2851-2011, 2011.

Gysel, M., Laborde, M., Mensah, A. A., Corbin, J. C., Keller, A., Kim, J., Petzold, A., and Sierau, B.: Technical Note: The single particle soot photometer fails to reliably detect PALAS soot nanoparticles, Atmos. Meas. Tech., 5, 3099-3107, https://doi.org/10.5194/amt-5-3099-2012, 2012.

Haynes, W. M., Lide, D. R., and Bruno, T. J. (Eds.): CRC handbook of chemistry and physics, 97th ed., CRC Press, 2017.

Haywood, J. and Boucher, O.: Estimates of the direct and indirect radiative forcing due to tropospheric aerosols: A review, Rev. Geophys., 38, 513-543, 2000.

He, L. Y., Hu, M., Huang, X. F., Yu, B. De, Zhang, Y. H., and Liu, D. Q.: Measurement of emissions of fine particulate organic matter from Chinese cooking, Atmos. Environ., 38, 6557-6564, https://doi.org/10.1016/j.atmosenv.2004.08.034, 2004.

Healy, R. M., Wang, J. M., Jeong, C., Lee, A. K. Y., Willis, M. D., Jaroudi, E., Zimmerman, N., Hilker, N., Murphy, M., Eckhardt, S., Stohl, A., Abbatt, J. P. D., Wenger, J. C., and Evans, G. J.: Light-absorbing properties of ambient black carbon and brown carbon from fossil fuel and biomass burning sources, J. Geophys. Res., 6619-6633, https://doi.org/10.1002/2015JD023382, 2015.

Henning, S., Wex, H., Hennig, T., Kiselev, A., Snider, J. R., Rose, D., Dusek, U., Frank, G. P., Pöschl, U., Kristensson, A., Bilde, M., Tillmann, R., Kiendler-Scharr, A., Mentel, T. F., Walter, S., Schneider, J., Wennrich, C., and Stratmann, F.: Soluble mass, hygroscopic growth, and droplet activation of coated soot particles during LACIS Experiment in November (LExNo), J. Geophys. Res.-Atmos., 115, 1-10, https://doi.org/10.1029/2009JD012626, 2010.

Henning, S., Ziese, M., Kiselev, A., Saathoff, H., Möhler, O., Mentel, T. F., Buchholz, A., Spindler, C., Michaud, V., Monier, M., Sellegri, K., and Stratmann, F.: Hygroscopic growth and droplet activation of soot particles: uncoated, succinic or 
sulfuric acid coated, Atmos. Chem. Phys., 12, 4525-4537, https://doi.org/10.5194/acp-12-4525-2012, 2012.

Hings, S. S., Wrobel, W. C., Cross, E. S., Worsnop, D. R., Davidovits, P., and Onasch, T. B.: CCN activation experiments with adipic acid: effect of particle phase and adipic acid coatings on soluble and insoluble particles, Atmos. Chem. Phys., 8, 37353748, https://doi.org/10.5194/acp-8-3735-2008, 2008.

IPCC: Climate Change 2013: The Physical Science Basis, Contribution of Working Group I to the Fifth Assessment Report of the Intergovernmental Panel on Climate Change, Cambridge University Press, Cambridge, United Kingdom and New York, NY, USA, https://doi.org/10.1017/CBO9781107415324, 2013.

Jimenez, J. L., Bahreini, R., Cocker III, D. R., Zhuang, H., Varutbangkul, V., Flagan, R. C., Seinfeld, J. H., O'Dowd, C. D., and Hoffmann, T.: New particle formation from photooxidation of diiodomethane $\left(\mathrm{CH}_{2} \mathrm{I}_{2}\right)$, J. Geophys. Res., 108, 4318, https://doi.org/10.1029/2002JD002452, 2003.

Jimenez, J. L., Canagaratna, M. R., Donahue, N. M., Prevot, A. S. H., Zhang, Q., Kroll, J. H., DeCarlo, P. F., Allan, J. D., Coe, H., Ng, N. L., Aiken, A. C., Docherty, K. S., Ulbrich, I. M., Grieshop, A. P., Robinson, A. L., Duplissy, J., Smith, J. D., Wilson, K. R., Lanz, V. A., Hueglin, C., Sun, Y. L., Tian, J., Laaksonen, A., Raatikainen, T., Rautiainen, J., Vaattovaara, P., Ehn, M., Kulmala, M., Tomlinson, J. M., Collins, D. R., Cubison, M. J., Dunlea, E. J., Huffman, J. A., Onasch, T. B., Alfarra, M. R., Williams, P. I., Bower, K., Kondo, Y., Schneider, J., Drewnick, F., Borrmann, S., Weimer, S., Demerjian, K., Salcedo, D., Cottrell, L., Griffin, R., Takami, A., Miyoshi, T., Hatakeyama, S., Shimono, A., Sun, J. Y., Zhang, Y. M., Dzepina, K., Kimmel, J. R., Sueper, D., Jayne, J. T., Herndon, S. C., Trimborn, A. M., Williams, L. R., Wood, E. C., Middlebrook, A. M., Kolb, C. E., Baltensperger, U., and Worsnop, D. R.: Evolution of organic aerosols in the atmosphere, Science, 326, 1525-1529, https://doi.org/10.1126/science.1180353, 2009.

Kawamura, K. and Yasui, O.: Diurnal changes in the distribution of dicarboxylic acids, ketocarboxylic acids and dicarbonyls in the urban Tokyo atmosphere, Atmos. Environ., 39, 1945-1960, https://doi.org/10.1016/j.atmosenv.2004.12.014, 2005.

Keskinen, H., Romakkaniemi, S., Jaatinen, A., Miettinen, P., Saukko, E., Jorma, J., Mäkelä, J. M., Virtanen, A., Smith, J. N., and Laaksonen, A.: On-line characterization of morphology and water adsorption on fumed silica nanoparticles, Aerosol Sci. Tech., 45, 1441-1447, https://doi.org/10.1080/02786826.2011.597459, 2011.

Khalizov, A. F., Xue, H., Wang, L., Zheng, J., Zhang, R., Khalizov, A. F., Xue, H., Wang, L., Zheng, J., and Zhang, R.: Enhanced Light Absorption and Scattering by Carbon Soot Aerosol Internally Mixed with Sulfuric Acid Enhanced Light Absorption and Scattering by Carbon Soot Aerosol Internally Mixed with Sulfuric Acid, J. Phys. Chem. A, 1066-1074, https://doi.org/10.1021/jp807531n, 2009.

Köhler, H.: The nucleus in and the growth of hygroscopic droplets, T. Faraday Soc., 32, 1152-1161, 1936.

Kumar, P., Sokolik, I. N., and Nenes, A.: Parameterization of cloud droplet formation for global and regional models: including adsorption activation from insoluble CCN, Atmos. Chem. Phys., 9, 2517-2532, https://doi.org/10.5194/acp-9-2517-2009, 2009.

Kumar, P., Sokolik, I. N., and Nenes, A.: Cloud condensation nuclei activity and droplet activation kinetics of wet processed regional dust samples and minerals, Atmos. Chem. Phys., 11, 8661-8676, https://doi.org/10.5194/acp-11-8661-2011, 2011.

Li, J. J., Wang, G. H., Cao, J. J., Wang, X. M., and Zhang, R. J.: Observation of biogenic secondary organic aerosols in the atmosphere of a mountain site in central China: temperature and relative humidity effects, Atmos. Chem. Phys., 13, 11535-11549, https://doi.org/10.5194/acp-13-11535-2013, 2013.

Liu, S., Aiken, A. C., Gorkowski, K., Dubey, M. K., Cappa, C. D., Williams, L. R., Herndon, S. C., Massoli, P., Fortner, E. C., Chhabra, P. S., Brooks, W. A., Onasch, T. B., Jayne, J. T., Worsnop, D. R., China, S., Sharma, N., Mazzoleni, C., Xu, L., Ng, N. L., Liu, D., Allan, J. D., Lee, J. D., Fleming, Z. L., Mohr, C., Zotter, P., Szidat, S., and Prévôt, A. S. H.: Enhanced light absorption by mixed source black and brown carbon particles in UK winter, Nat. Commun., 6, 8435, https://doi.org/10.1038/ncomms9435, 2015.

Lohmann, U. and Feichter, J.: Global indirect aerosol effects: a review, Atmos. Chem. Phys., 5, 715-737, https://doi.org/10.5194/acp-5-715-2005, 2005.

Mackay, J. and Mensah, G. A.: Atlas of heart disease and stroke, World Health Organization (WHO), Geneva, 2004.

Marr, L. C., Dzepina, K., Jimenez, J. L., Reisen, F., Bethel, H. L., Arey, J., Gaffney, J. S., Marley, N. A., Molina, L. T., and Molina, M. J.: Sources and transformations of particle-bound polycyclic aromatic hydrocarbons in Mexico City, Atmos. Chem. Phys., 6, 1733-1745, https://doi.org/10.5194/acp-6-1733-2006, 2006.

Maskey, S., Chong, K. Y., Seo, A., Park, M., Lee, K., and Park, K.: Cloud Condensation Nuclei Activation of Internally Mixed Black Carbon Particles, Aerosol Air Qual. Res., 17, 867-877, https://doi.org/10.4209/aaqr.2016.06.0229, 2017.

McCormick, R. A. and Ludwig, J. H.: Climate modification by atmospheric aerosols, Science, 156, 1358-1359, 1976.

Moffet, R. C. and Prather, K. A.: In-situ measurements of the mixing state and optical properties of soot with implications for radiative forcing estimates, P. Natl. Acad. Sci. USA, 106, 11872 11877, https://doi.org/10.1073/pnas.0900040106, 2009.

Onasch, T. B., Trimborn, A., Fortner, E. C., Jayne, J. T., Kok, G. L., Williams, L. R., Davidovits, P., and Worsnop, D. R.: Soot Particle Aerosol Mass Spectrometer: Development, Validation, and Initial Application, Aerosol Sci. Tech., 46, 804-817, https://doi.org/10.1080/02786826.2012.663948, 2012.

Pagels, J., Khalizov, A. F., McMurry, P. H., and Zhang, R. Y.: Processing of Soot by Controlled Sulphuric Acid and Water Condensation - Mass and Mobility Relationship, Aerosol Sci. Tech., 43 629-640, https://doi.org/10.1080/02786820902810685, 2009.

Peng, J., Hu, M., Guo, S., Du, Z., Zheng, J., Shang, D., Levy Zamora, M., Zeng, L., Shao, M., Wu, Y.-S., Zheng, J., Wang, Y., Glen, C. R., Collins, D. R., Molina, M J., and Zhang, R.: Markedly enhanced absorption and direct radiative forcing of black carbon under polluted urban environments, P. Natl. Acad. Sci. USA, 113, 4266-4271, https://doi.org/10.1073/pnas.1602310113, 2016.

Petters, M. D. and Kreidenweis, S. M.: A single parameter representation of hygroscopic growth and cloud condensation nucleus activity, Atmos. Chem. Phys., 7, 1961-1971, https://doi.org/10.5194/acp-7-1961-2007, 2007.

Petters, M. D., Kreidenweis, S. M., and Ziemann, P. J.: Prediction of cloud condensation nuclei activity for organic compounds using 
functional group contribution methods, Geosci. Model Dev., 9, 111-124, https://doi.org/10.5194/gmd-9-111-2016, 2016.

Pope, C. A. and Dockery, D. W.: Health effects of fine particulate air pollution?: lines that connect, J. Air Waste Manage., 56, 709$742,2006$.

Pope, C. A., Ezzati, M., and Dockery, D. W.: Fine-particulate air pollution and life expectancy in the United States, N. Engl. J. Med., 360, 376-386, 2009.

Ramanathan, V., Crutzen, P. J., Kiehl, J. T., and Rosenfeld, D.: Aerosols, climate, and the hydrological cycle, Science, 294, 2119-24, https://doi.org/10.1126/science.1064034, 2001.

Roberts, G. and Nenes, A.: A continuous-flow streamwise thermal-gradient $\mathrm{CCN}$ chamber for atmospheric measurements, Aerosol Sci. Tech., 39, 206-221, https://doi.org/10.1080/027868290913988, 2005.

Rogak, S. N. and Flagan, R. C.: Stokes drag on self-similar clusters of spheres, J. Colloid Interf. Sci., 134, 206-218, https://doi.org/10.1016/0021-9797(90)90268-S, 1990.

Rogge, W. F., Hildemann, L. M., Mazurek, M. A., Cass, G. R., and Simonelt, B. R. T.: Sources of Fine Organic Aerosol .1. Charbroilers and Meat Cooking Operations, Environ. Sci. Technol., 25, 1112-1125, https://doi.org/10.1021/es00018a015, 1991.

Saathoff, H., Naumann, K.-H., Schnaiter, M., Schöck, W., Möhler, O., Schurath, U., Weingartner, E., Gysel, M., and Baltensperger, U.: Coating of soot and $\left(\mathrm{NH}_{4}\right)_{2} \mathrm{SO}_{4}$ particles by ozonolysis products of $\alpha$-pinene, J. Aerosol Sci., 34, 1297-1321, https://doi.org/10.1016/S0021-8502(03)00364-1, 2003.

Salo, K., Jonsson, A. M., Andersson, P. U., and Hallquist, M.: Aerosol volatility and enthalpy of sublimation of carboxylic acids., J. Phys. Chem. A, 114, 4586-94, https://doi.org/10.1021/jp910105h, 2010.

Sedlacek, A. J., Lewis, E. R., Onasch, T. B., Lambe, A. T., and Davidovits, P.: Investigation of Refractory Black CarbonContaining Particle Morphologies Using the Single-Particle Soot Photometer (SP2), Aerosol Sci. Tech., 49, 872-885, https://doi.org/10.1080/02786826.2015.1074978, 2015.

Seinfeld, J. H. and Pandis, S. N.: Cloud physics, in Atmospheric Chemistry and Physics: From Air Pollution to Climate Change, chap. 15, John Wiley \& Sons, New York, 777-840, 2006.

Simoneit, B. R. T., Schauer, J. J., Nolte, C. G., Oros, D. R., Elias, V. O., Fraser, M. P., Rogge, W. F., and Cass, G. R.: Levoglucosan, a tracer for cellulose in biomass burning and atmospheric particles, Atmos. Environ., 33, 173-182, https://doi.org/10.1016/S13522310(98)00145-9, 1999.

Slezakova, K., Morais, S., and Pereira, M. do C.: Atmospheric Nanoparticles and Their Impacts on Public Health, in Current Topics in Public Health, edited by: Rodriguez-Morales, A. J., InTech, p. 732, 2013.

Slowik, J. G., Cross, E. S., Han, J.-H., Kolucki, J., Davidovits, P., Williams, L. R., Onasch, T. B., Jayne, J. T., Kolb, C. E., and Worsnop, D. R.: Measurements of Morphology Changes of Fractal Soot Particles using Coating and Denuding Experiments: Implications for Optical Absorption and Atmospheric Lifetime, Aerosol Sci. Tech., 41, 734-750, https://doi.org/10.1080/02786820701432632, 2007.

Soonsin, V., Zardini, A. A., Marcolli, C., Zuend, A., and Krieger, U. K.: The vapor pressures and activities of dicarboxylic acids reconsidered: the impact of the physical state of the aerosol, Atmos. Chem. Phys., 10, 11753-11767, https://doi.org/10.5194/acp-10-11753-2010, 2010.

Sorjamaa, R. and Laaksonen, A.: The effect of $\mathrm{H}_{2} \mathrm{O}$ adsorption on cloud drop activation of insoluble particles: a theoretical framework, Atmos. Chem. Phys., 7, 6175-6180, https://doi.org/10.5194/acp-7-6175-2007, 2007.

Stratmann, F., Bilde, M., Dusek, U., Frank, G. P., Hennig, T., Henning, S., Scharr, A. K., Kiselev, A., Kristensson, A., Lieberwirth, I., Mentel, T. F., Pöschl, U., Rose, D., Schneider, J., Snider, J. R., Tillmann, R., Walter, S., and Wex, H.: Examination of laboratory - generated coated soot particles?: An overview of the LACIS Experiment in November (LExNo) campaign, J. Geophys. Res., 115, 1-12, https://doi.org/10.1029/2009JD012628, 2010.

Ström, J., Okada, K., and Heintzenberg, J.: On the state of mixing of particles due to Brownian coagulation, J. Aerosol Sci., 23, 467480, https://doi.org/10.1016/0021-8502(92)90018-Q, 1992.

Tranfield, E. M. and Walker, D. C.: Understanding of Human Illness and Death Following Exposure to Particulate Matter Air Pollution, in Environmental Health - Emerging Issues and Practice, edited by: Oosthuizen, J., InTech, 81-102, 2012.

Tritscher, T., Juanyi, Z., Martin, M., Chirico, R., Gysel, M., Heringa, M. F., DeCarlo, P. F., Sierau, B., Prevot, A. S. H., Weingartner, E., and Baltensperger, U.: Changes of hygroscopicity and morphology during ageing of diesel soot, Environ. Res. Lett., 6, 1-10, https://doi.org/10.1088/1748-9326/6/3/034026, 2011.

Twomey, S.: Pollution and the planetary albedo, Atmos. Environ., 8, 1251-1256, 1974.

Virtanen, A., Ristimäki, J., and Keskinen, J.: Method for measuring effective density and fractal dimension of aerosol agglomerates, Aerosol Sci. Tech., 38, 437-446, https://doi.org/10.1080/02786820490445155, 2004.

Willis, M. D., Lee, A. K. Y., Onasch, T. B., Fortner, E. C., Williams, L. R., Lambe, A. T., Worsnop, D. R., and Abbatt, J. P. D.: Collection efficiency of the soot-particle aerosol mass spectrometer (SP-AMS) for internally mixed particulate black carbon, Atmos. Meas. Tech., 7, 4507-4516, https://doi.org/10.5194/amt-7-45072014, 2014.

Winklmayr, W., Reischl, G. P., Lindner, A. O., and Berner, A.: A new electromobility spectrometer for the measurement of aerosol size distributions in the size range from 1 to $1000 \mathrm{~nm}$, J. Aerosol Sci., 22, 289-296, https://doi.org/10.1016/S00218502(05)80007-2, 1991.

Xu, X., Zhao, W., Qian, X., Wang, S., Fang, B., Zhang, Q., Zhang, W., Venables, D. S., Chen, W., Huang, Y., Deng, X., Wu, B., Lin, X., Zhao, S., and Tong, Y.: Influence of photochemical aging on light absorption of atmospheric black carbon and aerosol single scattering albedo, Atmos. Chem. Phys. Discuss., https://doi.org/10.5194/acp-2018-59, in review, 2018.

Zamora, I. R., Tabazadeh, A., Golden, D. M., and Jacobson, M. Z.: Hygroscopic growth of common organic aerosol solutes, including humic substances, as derived from water activity measurements, J. Geophys. Res.-Atmos., 116, 1-12, https://doi.org/10.1029/2011JD016067, 2011.

Zhang, R., Khalizov, A. F., Pagels, J., Zhang, D., Xue, H., and Mcmurry, P. H.: Variability in morphology, hygroscopicity, and optical properties of soot aerosols during atmospheric processing, P. Natl. Acad. Sci. USA, 105, 10291-10296, 2008.

Zhang, Y., Zhang, Q., Cheng, Y., Su, H., Kecorius, S., Wang, Z., Wu, Z., Hu, M., Zhu, T., Wiedensohler, A., and He, K.: Measur- 
ing the morphology and density of internally mixed black carbon with SP2 and VTDMA: new insight into the absorption enhancement of black carbon in the atmosphere, Atmos. Meas. Tech., 9, 1833-1843, https://doi.org/10.5194/amt-9-1833-2016, 2016.
Zhang, Y., Zhang, Q., Cheng, Y., Su, H., Li, H., Li, M., Zhang, X., Ding, A., and He, K.: Amplification of light absorption of black carbon associated with air pollution, Atmos. Chem. Phys., 18, 9879-9896, https://doi.org/10.5194/acp-18-9879-2018, 2018. 